University of Wisconsin Milwaukee

UWM Digital Commons

Geography Faculty Articles

Geography

2012

\title{
A spatio-temporal analysis of groundwater level changes in relation to urban growth and groundwater recharge potential for Waukesha County, Wisconsin
}

Woonsup Choi

University of Wisconsin - Milwaukee, choiw@uwm.edu

Ulrike Galasinski

University of Wisconsin - Milwaukee

Sung-Jin Cho

Kyung Hee University

Chul-sue Hwang

Kyung Hee University

Follow this and additional works at: https://dc.uwm.edu/geog_facart

Part of the Physical and Environmental Geography Commons

\section{Recommended Citation}

Choi, Woonsup; Galasinski, Ulrike; Cho, Sung-Jin; and Hwang, Chul-sue, "A spatio-temporal analysis of groundwater level changes in relation to urban growth and groundwater recharge potential for Waukesha County, Wisconsin" (2012). Geography Faculty Articles. 3.

https://dc.uwm.edu/geog_facart/3 


\section{A spatio-temporal analysis of groundwater level changes in relation to urban growth and groundwater recharge potential for Waukesha County, Wisconsin}

Note: This is the author's version of a work that was accepted for publication in Geographical Analysis. Changes resulting from the publishing process, such as peer review, editing, corrections, structural formatting, and other quality control mechanisms may not be reflected in this document. Changes may have been made to this work since it was submitted for publication. A definitive version was subsequently published in Geographical Analysis, 2012, vol. 44, pp. 219-234, DOI: 10.1111/j.1538-4632.2012.00848.x

Woonsup Choi* (choiw@uwm.edu)

Ulrike Galasinski*

Sung-Jin Cho

Chul-sue Hwang ${ }^{\#}$

*University of Wisconsin-Milwaukee, Milwaukee, Wisconsin, USA

\#Kyung Hee University, Seoul, Republic of Korea 


\begin{abstract}
The main objective of this study was to spatially and temporally analyze groundwater level changes using geographic information systems and spatial analysis with respect to urban development, groundwater water withdrawal, and groundwater recharge potential. The study focused on Waukesha County in southeastern Wisconsin, where urban development has been accelerating while groundwater has been declining during the last several decades. We analyzed data about groundwater withdrawal, groundwater level, land use/land cover, and precipitation utilizing correlation analysis, Geographically Weighted Regression (GWR), land-use change analysis, and map overlay. As a result, we found that (1) Urban areas increased faster in areas with high recharge potential than in areas with low or moderate recharge potential, (2) The effect of urban growth on groundwater level is highly variable by time and space, and (3) The changes in groundwater level are strongly related to the spatial distribution of groundwater withdrawal. The study pinpoints the need to consider the spatial unevenness of groundwater withdrawal in understanding the changes in groundwater level and groundwater recharge potential for better managing groundwater resources.
\end{abstract}

Keywords: groundwater; potentiometric surface; urban development; permeability; geographically weighted regression 


\section{Introduction}

Groundwater is a valuable source of drinking water and its availability critically affects the development and prosperity of a region (Jaiswal et al. 2003). However, cases of water shortages due to depleted groundwater resources occur more and more frequently worldwide and are not intrinsic to arid regions (Vazquez-Sune et al. 2005).

Research has shown that impervious urban surfaces, such as roads, buildings, driveways, and parking lots, result in diminished groundwater recharge in many regions. Zellner (2007) estimated that the groundwater recharge potential of a oneacre $\left(4046.856 \mathrm{~m}^{2}\right)$ parking lot in Monroe County, Michigan is $16 \%$ less compared to the recharge potential of a one-acre undeveloped area in its natural state. Erickson and Stefan (2009) quantified the relative change of natural direct groundwater recharge from precipitation for varying degrees of urban development in the Vermillion River Watershed in Minnesota. Overall they found a 30 to $40 \%$ reduction in groundwater recharge with a 30\% increase in urban development. Jat et al. (2009) and Rose and Peters (2001) found that the groundwater decline increased with a reduction in recharge due to a conversion of pervious into impervious urban areas in Rajasthan State, India, and Georgia, USA, respectively. Shaban et al. (2006) and Yeh et al. (2009) found that agricultural areas and areas with general vegetation cover have high infiltration rates and therefore higher groundwater recharge rates, while highly populated areas have the smallest recharge potential rate. Similarly, He et al. (2009) found that the regional urban groundwater table decreased when the rice paddy field area decreased and the urban area increased in the coastal Dogo Plain, Japan.

The potential for groundwater recharge is complex and not uniform over a groundwater recharge area. Therefore the actual recharge potential of groundwater recharge zones has to be estimated (Lorenz and Delin 2007). Groundwater recharge potential is influenced by a variety of factors including topography, vegetation and land cover, geology, soil types, drainage density, and forms of land use within a recharge area (Jaiswal et al. 2003). Considering the large number of components that influence groundwater recharge potential, geographic information systems (GIS) and groundwater models are useful tools to assess the potential. For example, groundwater depletion is mapped with the urban growth by time, or recharge zones are overlaid with different recharge potentials from excellent to poor determined by a panel of factors such as soil type (Cho et al. 2009; Jat et al. 2009; Yeh et al. 2009; Jasrotia et al. 2007; Jaiswal et al. 2003).

Previous research has demonstrated the detrimental effect impervious urban surfaces have on groundwater recharge. Some of the research emphasizes that groundwater recharge potential is variable and not uniform over a groundwater recharge area. Overall, previous studies were conducted without much spatial aspect (e.g. Erickson and Stefan 2009; Rose and Peters 2001) or did not consider urban development, actual groundwater level changes, and groundwater recharge potential simultaneously (e.g. Yeh et al. 2009; Jaiswal et al. 2003). In addition, the aforementioned studies that 
used GIS for groundwater research did not adopt spatial analysis techniques to explain the spatial variability of groundwater level or recharge. For example, a regression model that estimated groundwater recharge across Minnesota was built (Lorenz and Delin 2007) but it did not address spatially varying relationships among the variables. As a result, even though the model explains the variability of groundwater recharge generally well, it does not reveal which explanatory variables are more (or less) influential and where.

The main objective of this study was to spatially and temporally analyze groundwater level changes using GIS and spatial analysis in relation to urban development, groundwater water withdrawal, and groundwater recharge potential. The study focused on Waukesha County in southeastern Wisconsin, where urban development has been accelerating while groundwater has been declining during the last several decades. Despite the known problems, there is lack of research conducted to address the variability of groundwater recharge potential or specifically the negative impact of urbanization on groundwater in Waukesha County or elsewhere in Wisconsin. It was demonstrated for some parts of Wisconsin that it is essential to include groundwater recharge for effective groundwater modeling and management (Dripps and Bradbury 2007). The groundwater recharge potential is known to be not uniform throughout Waukesha County due to the unique underlying geology. Parts of the aquifer underlying Waukesha County are confined and cut off from recharge through infiltrated precipitation. Seventeen counties with similar aquifer characteristics to Waukesha exist in Wisconsin alone and some can be found in Northeastern Illinois (GLWI 2007). These features could make groundwater research in Waukesha County a precedent for other municipalities.

\section{Study Area}

Waukesha County, the study area, is located between the latitudes $42^{\circ} 84^{\prime} \mathrm{N}$ to $43^{\circ} 20^{\prime}$ $\mathrm{N}$ and longitudes $88^{\circ} 06^{\prime} \mathrm{W}$ to $88^{\circ} 55^{\prime} \mathrm{W}$ (Figure 1) which situates it about $15 \mathrm{~km}$ west of Lake Michigan. The City of Milwaukee, the largest city in Wisconsin, is located in between. The areal extent of Waukesha County is $1,502.94 \mathrm{~km}^{2}$. The population of Waukesha County was 360,800 in the year 2000, and with an intermediate growth rate, it is expected to rise to 446,800 in 2035, as estimated from past growth rates (SEWRPC 2004, p. 52). 

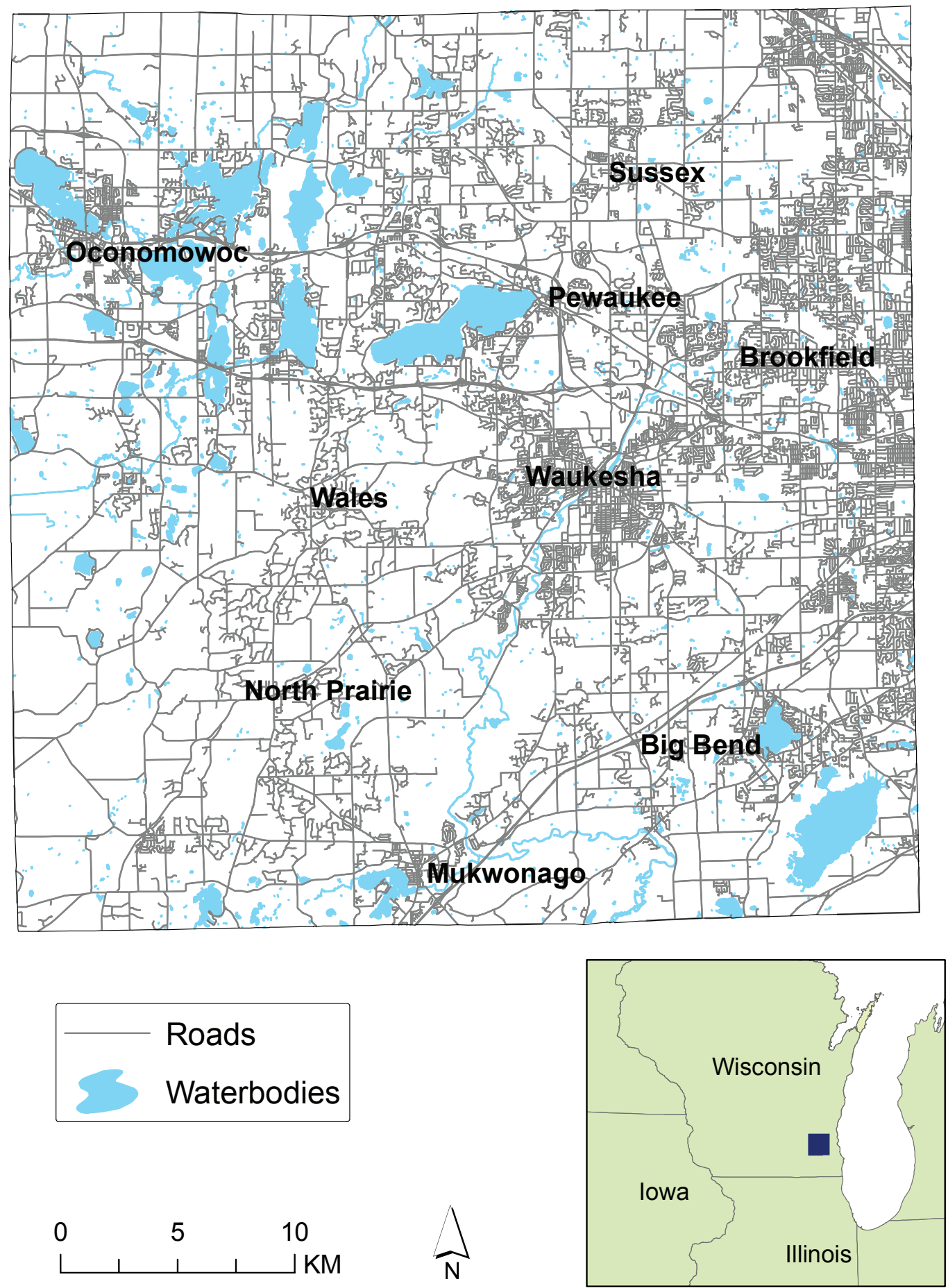

Figure 1. Location map of the study area

Waukesha County derives its water mostly through municipal and industrial wells (SEWRPC 2002). Figure 2 shows the location of wells for which estimated withdrawal data are available since the late $19^{\text {th }}$ century (Buchwald et al. 2010). The Quaternary sand and gravel aquifer covers roughly western half of the county, and the 
Silurian dolomite aquifer extends in the eastern half of the county, with Quaternary glacier deposits on top. Beneath the Silurian dolomite aquifer is the Maquoketa Confining Unit, a nearly impermeable shale layer that extends under Lake Michigan and restricts seepage of precipitation into the deep aquifer for groundwater recharge in the eastern part of the county. There are sandstone aquifers formed in the Ordovician and Cambrian Periods underneath the Maquoketa Confining Unit and they extend across the county. Therefore the deep sandstone aquifers are much more subject to recharge from the surface in the western part of the county than in the eastern party of the county.

The underlying geology and permeability define distinct areas with naturally varying degrees of groundwater recharge potential throughout Waukesha County (Figure 2) (SEWRPC 2002). They were delineated based on the property of deposits during the Wisconsin Glaciation, and reflect the estimates of hydraulic conductivity of the material. The zone of moderate permeability, with estimated hydraulic conductivity of $1 \times 10^{-4}-1 \times 10^{-3} \mathrm{~cm} / \mathrm{s}$, has the largest areal extent with $756.45 \mathrm{~km}^{2}$. The low permeability zone has estimated hydraulic conductivity of less than $1 \times 10^{-5} \mathrm{~cm} / \mathrm{s}$, extends over $256.46 \mathrm{~km}^{2}$ and is located mostly in the eastern corridor of the county. The high permeability zone has estimated hydraulic conductivity of larger than $1 \times 10^{-3}$ $\mathrm{cm} / \mathrm{s}$ and extends over $437.62 \mathrm{~km}^{2}$. Natural infiltration in the western part of the county flows eastward only very slowly. The water is pumped from the deep aquifer at a rate about ten times greater than its replenishing rate. As a result, water levels in the deep aquifer are declining, and the water does not meet the US Environmental Protection Agency's standards for naturally occurring radium anymore. Currently Waukesha County is considering sustainable water supply possibilities and ways to protect the existing groundwater resources (GLWI 2007). 

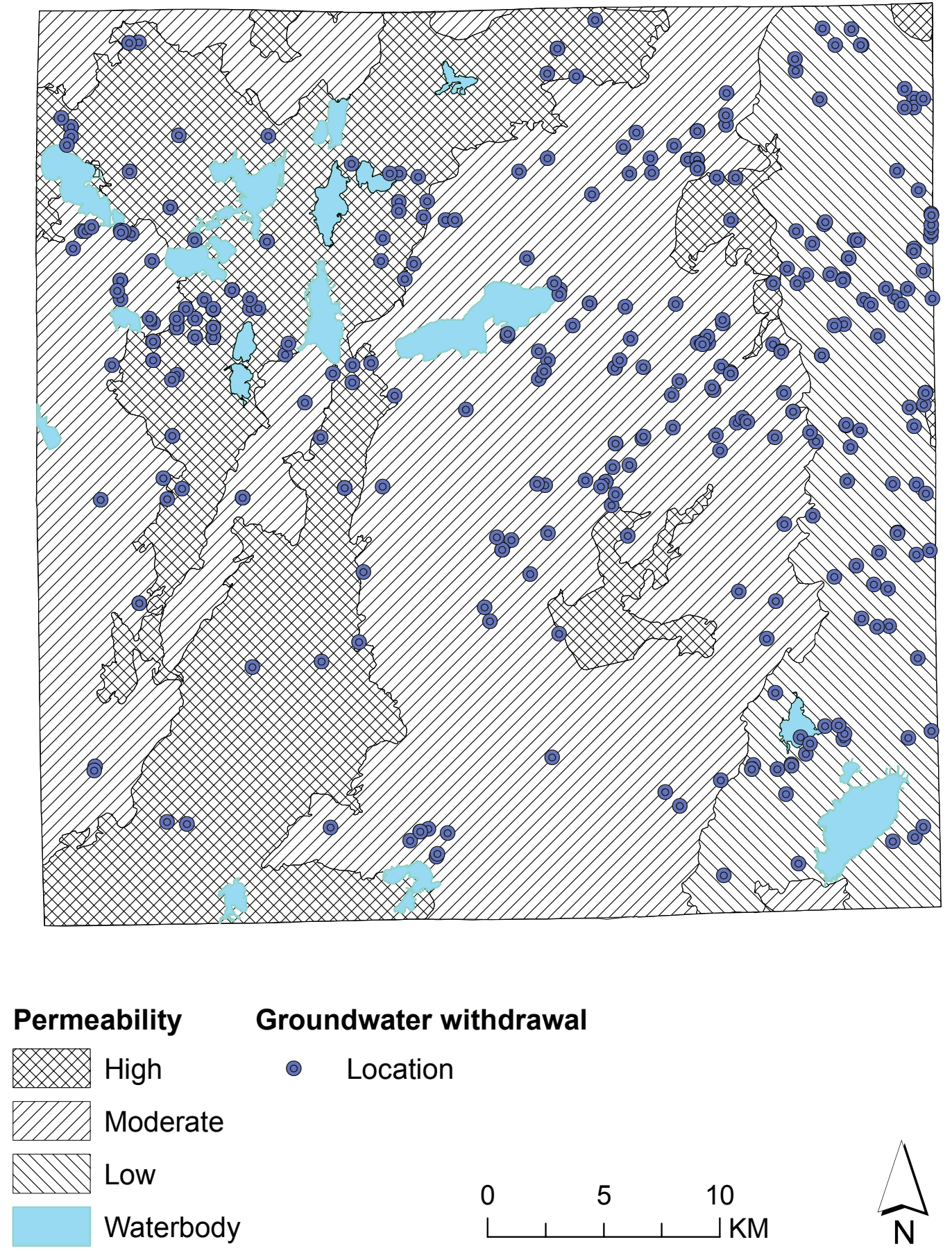

Figure 2. Estimated permeability of the unsaturated zone and location of groundwater withdrawal in Waukesha County (data courtesy of Wisconsin Geological and Natural History Survey and US Geological Survey) 


\section{Data Used}

\section{Groundwater data}

Data on estimated total Waukesha County groundwater withdrawals (in millions of liters per day) between 1864 and 2005 from the aquifer system below Waukesha County were obtained from Cheryl Buchwald, a US Geological Survey (USGS) Hydrologist and Water-Use Specialist at the Wisconsin Water Science Center (Buchwald et al. 2010). The withdrawals have been extracted from the USGS-created Lake Michigan Basin Groundwater Model.

Waukesha County extracts most of groundwater from a confined aquifer, and the groundwater in a confined aquifer is pressurized. Therefore, confined aquifers do not have a water table. Instead, the groundwater rises above the top confining geological layer when a well penetrates through the confining unit. The level to which the groundwater rises above the confining rock layer is the potentiometric surface measured in meters above mean sea level. Estimates of the potentiometric surface under Waukesha County were obtained from Daniel Feinstein of the USGS in 2010 as contour map images for selected years between 1864 and 2000. The mean potentiometric surface values for the high, moderate, and low permeability zones for the same years were calculated as well.

\section{Land-use data}

A data set describing the progression of urban growth in Waukesha County was obtained from Donald Dittmar, a Geographic Information Systems Professional and Waukesha County Land Information System Division Manager, in April 2010. The numerical data set contained the percentage of Waukesha County covered with urban development for selected years between 1850 and 2000.

Waukesha County land use data were obtained in the form of ArcGIS ${ }^{\circledR}$ compatible shapefiles from the Southeastern Wisconsin Regional Planning Commission (SEWRPC) for the years 1963, 1970, 1980, 1990, and 2000. The dataset differs from the overall degree of urban development in Waukesha County mentioned previously in that it contains spatial (location of urban development) as well as non-spatial (type of urban development) information. We aggregated the numerous land use classes into seven overarching classes as indicated by the SEWRPC land use classifications and codes (Table 1). Classes I through III contain the majority of all impermeable urban surfaces. The impact of the three classes will be most negative on aquifer recharge due to their high content of impervious surface. Overall the classes are arranged hierarchically, class I having the most negative impact on recharge and class VII having the least or no negative impact on groundwater recharge. 
Table 1. Aggregation of SEWRPC land use classes into seven representative land use classes

\begin{tabular}{l|l}
\hline I. Transportation & $\begin{array}{l}\text { Freeway; Standard Arterial Street; Local and Collector Street; } \\
\text { Bus Terminal; Multi-Purpose Off-Street Parking Area; Single- } \\
\text { Purpose Off-Street Parking-Area; Airfields; Transportation } \\
\text { Land Under Development }\end{array}$ \\
\hline II. Industrial and & $\begin{array}{l}\text { Retail Sales and Services--Intensive; Retail Sales and Services- } \\
\text {-Nonintensive; Commercial Land Under Development; } \\
\text { Manufacturing; Wholesaling and Storage; Extractive; } \\
\text { Industrial Land Under Development; Truck Terminal; Railroad } \\
\text { Right-of-Way; Railroad Switching Yard; Railroad Stations and } \\
\text { Depot; Air Terminals and Hangars; Ship Terminals; } \\
\text { Communication and Utilities; Communications and Utilities } \\
\text { Under Development; Administration, Safety and Assembly; } \\
\text { Education; Group Quarters; Governmental and Institutional } \\
\text { Land Under Development; Special and Cultural Recreation } \\
\text { Areas; Farm Buildings; Landfill }\end{array}$ \\
\hline III. Residential & $\begin{array}{l}\text { Single-family, nonfarm; Single-family farm; Two-family; } \\
\text { Multi-family, one to three stories high; Multi-family, four or } \\
\text { more stories high; Mobile Home; Residential Land Under }\end{array}$ \\
\hline Development
\end{tabular}

\section{Precipitation data}

Since groundwater is recharged in a natural setting by infiltration of precipitation into the ground, precipitation data were also examined. Precipitation data for Waukesha County were obtained from the National Climatic Data Center of the National Oceanic and Atmospheric Administration (NOAA). Annual climatological summaries were available for two stations in Waukesha County (http://cdo.ncdc.noaa.gov, last accessed on 25 July 2010). Total annual precipitation was available for 73 years between 1931 and 2009 for the Waukesha station (Elev. $253 \mathrm{~m}$ above sea level; Lat. $43^{\circ} 00^{\prime} \mathrm{N}$, Lon. $\left.88^{\circ} 15^{\prime} \mathrm{W}\right)$ and for 62 years between 1945 and 2000 for the Oconomowoc station (Elev. $261 \mathrm{~m}$ above sea level; Lat. $43^{\circ} 06^{\prime} \mathrm{N}$, Lon. $\left.88^{\circ} 30^{\prime} \mathrm{W}\right)$. Figure 3 shows that total annual precipitation for the NOAA stations in Waukesha and Oconomowoc has been increasing during the last decades. The 
trend is statistically significant $(p<0.01)$ according to the Mann-Kendall test for trend.

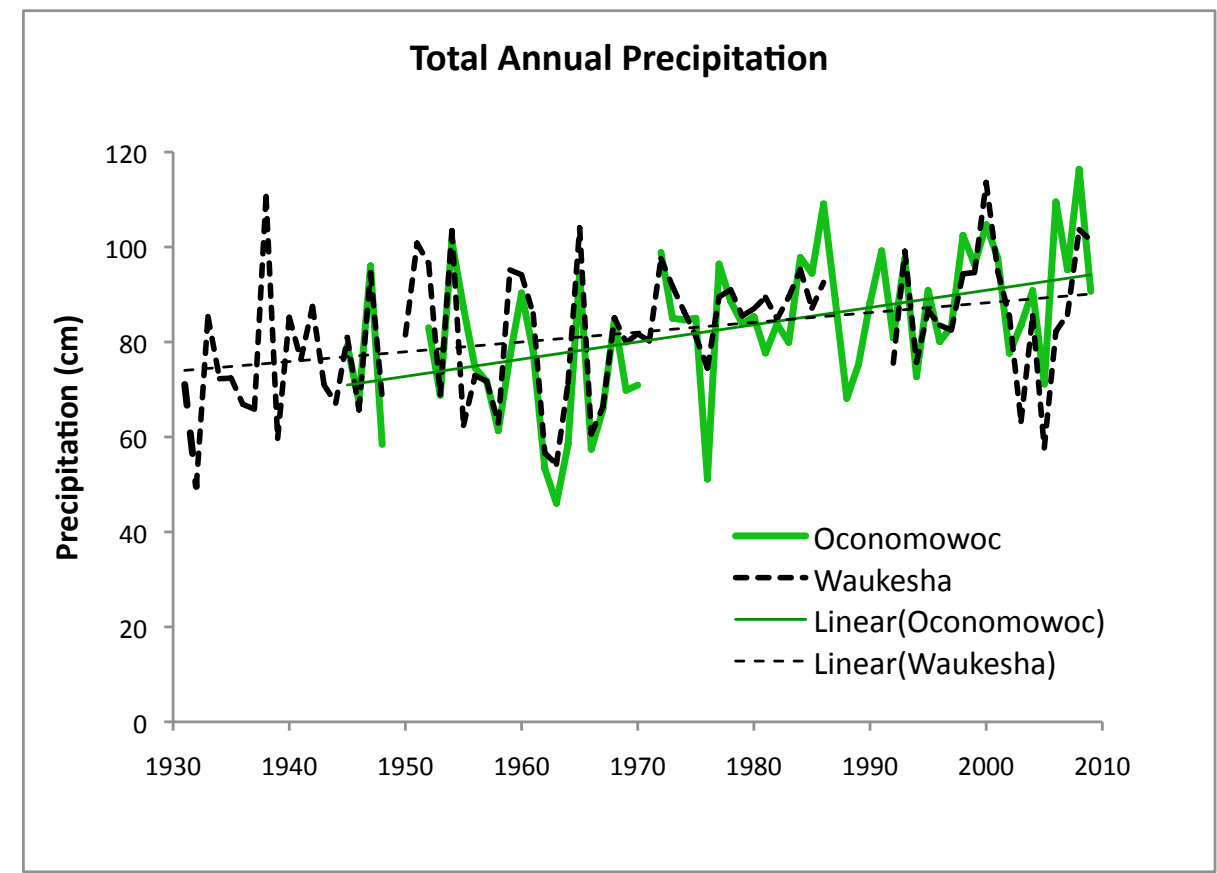

Figure 3. Annual precipitation in Waukesha County measured at Waukesha and Oconomowoc stations

\section{Analysis Methods}

\section{Correlation}

To understand an overall relationship between the Waukesha County variables (potentiometric surface, total groundwater withdrawals, and degree of urbanization), a correlation analysis was performed $(\mathrm{N}=11)$. The sample size represents the years for which data are available. It should be noted that the data for each year were averaged for the entire county, and thus have no spatial dimension. The correlation analysis was performed for each permeability zone as well, because in areas of high subsurface permeability impervious surfaces diminish natural groundwater recharge while in areas of low subsurface permeability natural groundwater recharge is already low due to geological characteristics and thus impervious surfaces have smaller impact on recharge. Due to the lack of detailed land use data prior to 1963, only five observations regarding the potentiometric surface and the other variables could be obtained. 


\section{Geographically Weighted Regression}

The Geographically Weighted Regression (GWR) is a technique to analyze the spatially varying relationship between variables (Fotheringham et al. 2002). GWR builds a regression model for each observation of the dependent variable on space using explanatory variables with different weights based on their location. The weight for an explanatory variable at observation $i$ is determined using the following equation:

$w_{i}(\mathrm{~g})=\exp (-d / h)^{2}$

where $\mathrm{g}$ is the vector that determines the coordinate of the dependent variable, $d$ is the distance between the dependent variable at $\mathrm{g}$ and the explanatory variable at $i$, and $h$ is the bandwidth. If $h$ is infinity, the regression model becomes a global one. The observations of the explanatory variables located closer to the dependent variable have stronger influence that those farther away.

We implemented GWR to understand relationships between the potentiometric surface and explanatory variables including the degree of urbanization, permeability and percolation for each of the years 1970, 1980, 1990, and 2000. We assumed that permeability and percolation remained constant. We converted the vector GIS data into raster format with a cell size of $15.24 \mathrm{~m} \times 15.24 \mathrm{~m}(50 \mathrm{feet} \times 50$ feet). Then we divided the study area into a matrix of cells and superimposed them on the raster GIS datasets. We tried four different numbers of cells, $2500(50 \times 50), 1600(40 \times 40)$, $900(30 \times 30)$ and $400(20 \times 20)$, to account for the modifiable areal unit problem. The cell size of the $50 \times 50$ grid is approximately $778 \mathrm{~m} \times 778 \mathrm{~m}$ and that of the $40 \times$ 40 grid is approximately $973 \mathrm{~m} \times 973 \mathrm{~m}$. The value of each grid cell was determined by summing the corresponding cell values from the raster datasets and was regarded as an observation of the variable. The bandwidth was determined with the corrected Akaike Information Criterion (AICc) option on ArcGIS ${ }^{\circledR}$.

\section{Land use change analysis}

The extent of urban land uses was analyzed both temporally and spatially. The area of urban land uses were calculated for each recharge potential zone and plotted against time. The extent of urban areas was compared between 1963 and 2000 and mapped together. In addition, we examined perimeter-to-area ratios of urban areas in Waukesha County because it is suggested that small perimeter-to-area ratios of urban areas help reduce the stress of urban areas on neighboring groundwater recharge areas (Zellner 2007). Utilizing the SEWRPC land use shapefiles and ArcGIS ${ }^{\circledR}$, polygons of the land use classes I, II, and III were merged into one urban class. The urban class' areal extent (in square kilometers) and perimeter (in kilometers) were calculated for the years 1963, 1970, 1980, 1990, and 2000 and perimeter-to-area ratios were calculated by dividing perimeter values by area values. 


\section{Map overlay}

Maps showing changes in the potentiometric surface were overlaid with other spatial datasets. To make the maps showing changes in the potentiometric surface, we georeferenced contour map images of the potentiometric surface for the selected years between 1864 and 2000 generated by the USGS regional groundwater model (Mean RMSE $=0.079663$ ) and digitized the contour lines. Then we converted the resulting polygon shapefiles into raster datasets with the ArcGIS ${ }^{\circledR}$ software. In doing so, we utilized the polygon-to-raster tool and assigned cell values based on the maximum area option. The maximum area method assigned the potentiometric surface value of the polygon to the cell which covered the largest amount of the cells area. Following, the cell values for each created raster were averaged to obtain the mean potentiometric surface for Waukesha County for every ten years between 1900 and 2000. The resulting maps were overlaid with the permeability and land use data.

\section{Results}

\section{Relationship among time series variables}

The obtained scatterplot matrix indicates that a strong correlation exists between all three variables (Figure 4). Potentiometric surface has a strong negative correlation with the degree of urbanization $(\mathrm{r}=-0.922)$ as well as total groundwater withdrawals $(\mathrm{r}=-0.908)$. The degree of urbanization and total groundwater withdrawals have a strong positive correlation $(\mathrm{r}=0.986)$ with each other. The correlation is significant in all cases at the 0.01 level. 


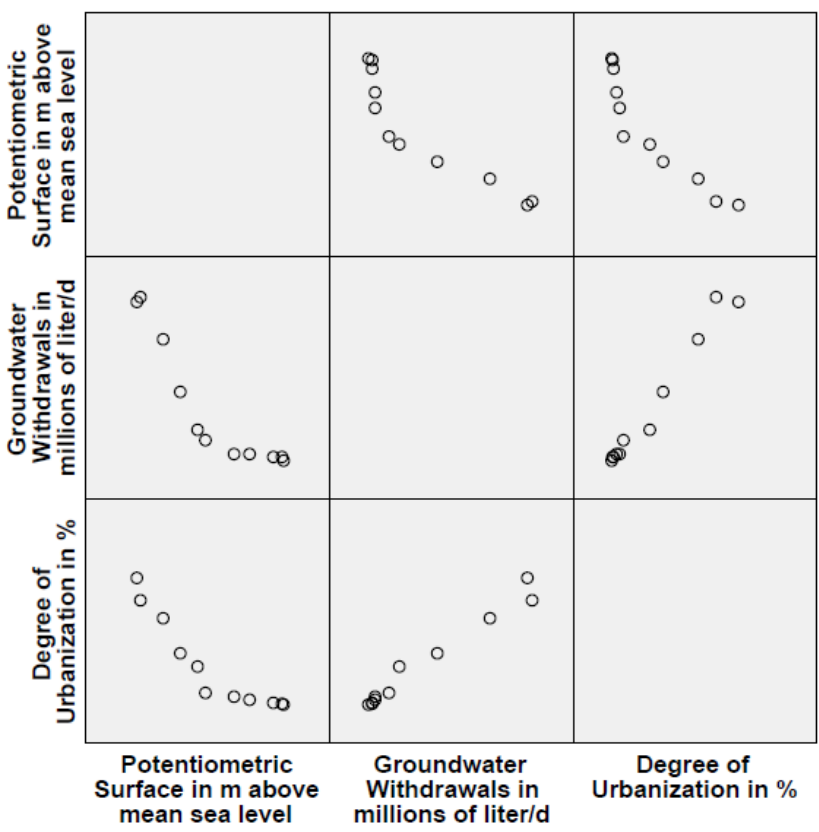

Figure 4. Scatterplot matrix for the Waukesha County variables: potentiometric surface, total groundwater withdrawals, and degree of urbanization

The correlation analysis in each permeability zone $(\mathrm{N}=5)$ supported the previous assumptions. In the area of low permeability, groundwater withdrawals and potentiometric surface have the strongest significant correlation $(r=-0.991, p=$ 0.001 ) while the correlation between potentiometric surface and the degree of urbanization is not significant $(r=-0.809, p=0.097)$. At the same time, in the area of high permeability, potentiometric surface and the degree of urbanization have a strong significant correlation $(\mathrm{r}=-0.919, \mathrm{p}=0.027)$ while the correlation between potentiometric surface and groundwater withdrawals is not significant $(\mathrm{r}=-0.81, \mathrm{p}=$ 0.097).

The trends of the potentiometric surface, total groundwater withdrawals, and degrees of development are shown in Figure 5. While the potentiometric surface of the aquifer shows a steady and nearly linear decline from 1900 to 2000, total groundwater withdrawals and the extent of urban development have experienced a slow increase until about 1940. After 1940 the total groundwater withdrawals and the extent of urban development experienced exponential growth. Only groundwater withdrawals show a reverse in trend after 50 years of exponential growth with a slight decline in groundwater withdrawals after 1990. 


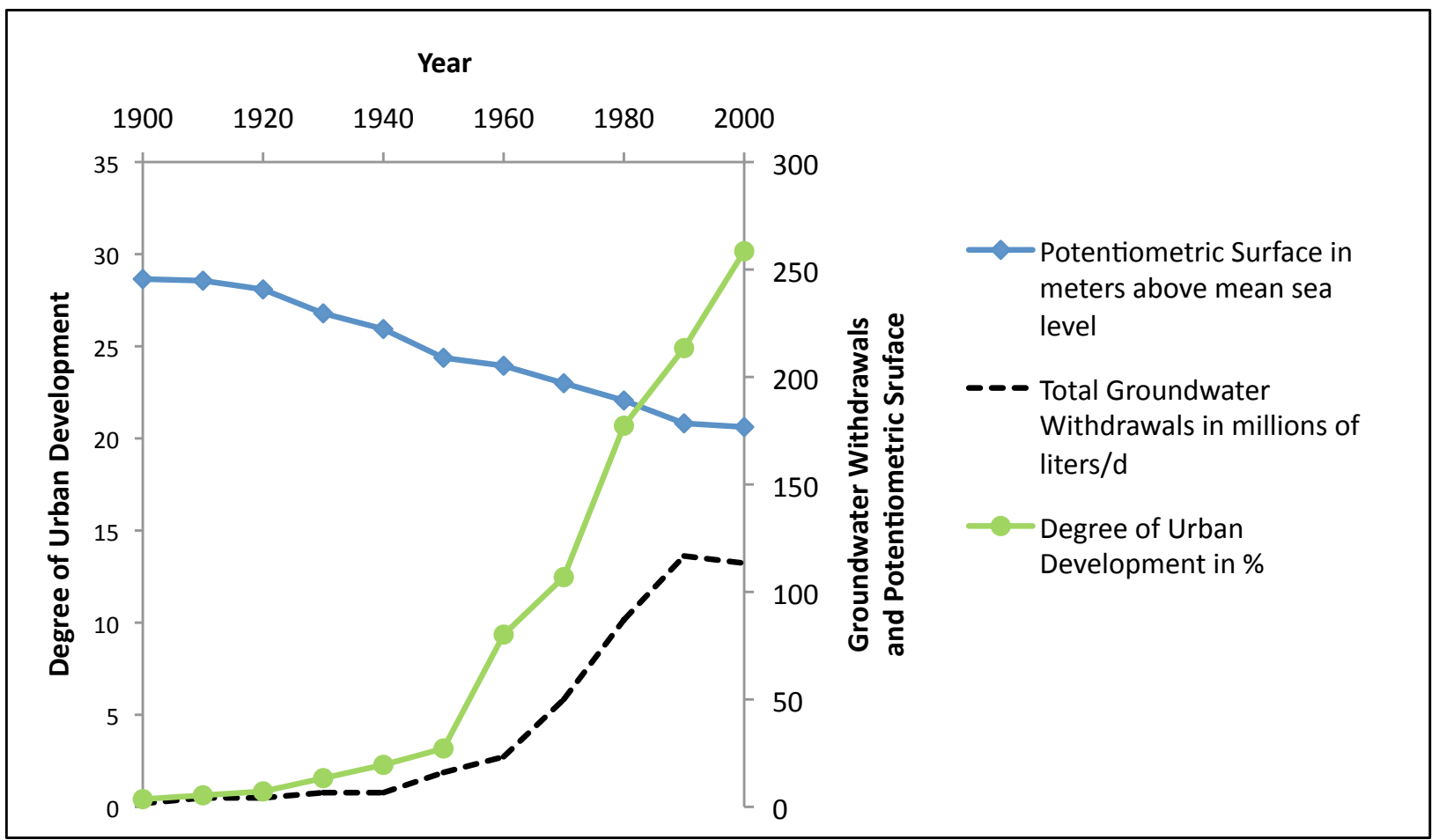

Figure 5. Trends of the potentiometric surface, total groundwater withdrawals, and degree of urban development in Waukesha County from 1900 to 2000

\section{Relationship among spatial variables}

The results the Geographically Weighted Regression model with the 1600 grid cells are presented in Figure 6. It shows varying regression coefficients for the degree of urbanization on the potentiometric surface between 1970 and 2000 when other explanatory variables are held constant. In 1970, the central corridor of the study region shows stronger effects of urbanization on the potentiometric surface while eastern and western ends show weaker ones. At that time most of groundwater withdrawals were concentrated in the eastern half of the county. Therefore urbanization has a stronger effect on the potentiometric surface in the central corridor than in the eastern edge or in the western edge where there was very little development.

Urban areas substantially expanded between 1970 and 1980 across the county, but the urbanization effect generally weakened in the central and eastern parts compared to the western edge. During the period the potentiometric surface decreased mostly in the eastern half of the county where most of the wells are located. The western edge still remained largely undeveloped during the period, and the potentiometric surface was largely homogeneous in this area. New development scattered in the area is believed to have contributed to stronger effects of urbanization in the western edge. The effect of urbanization grew stronger in the western edge through 2000, as the potentiometric surfaced decreased and urban areas expanded. 

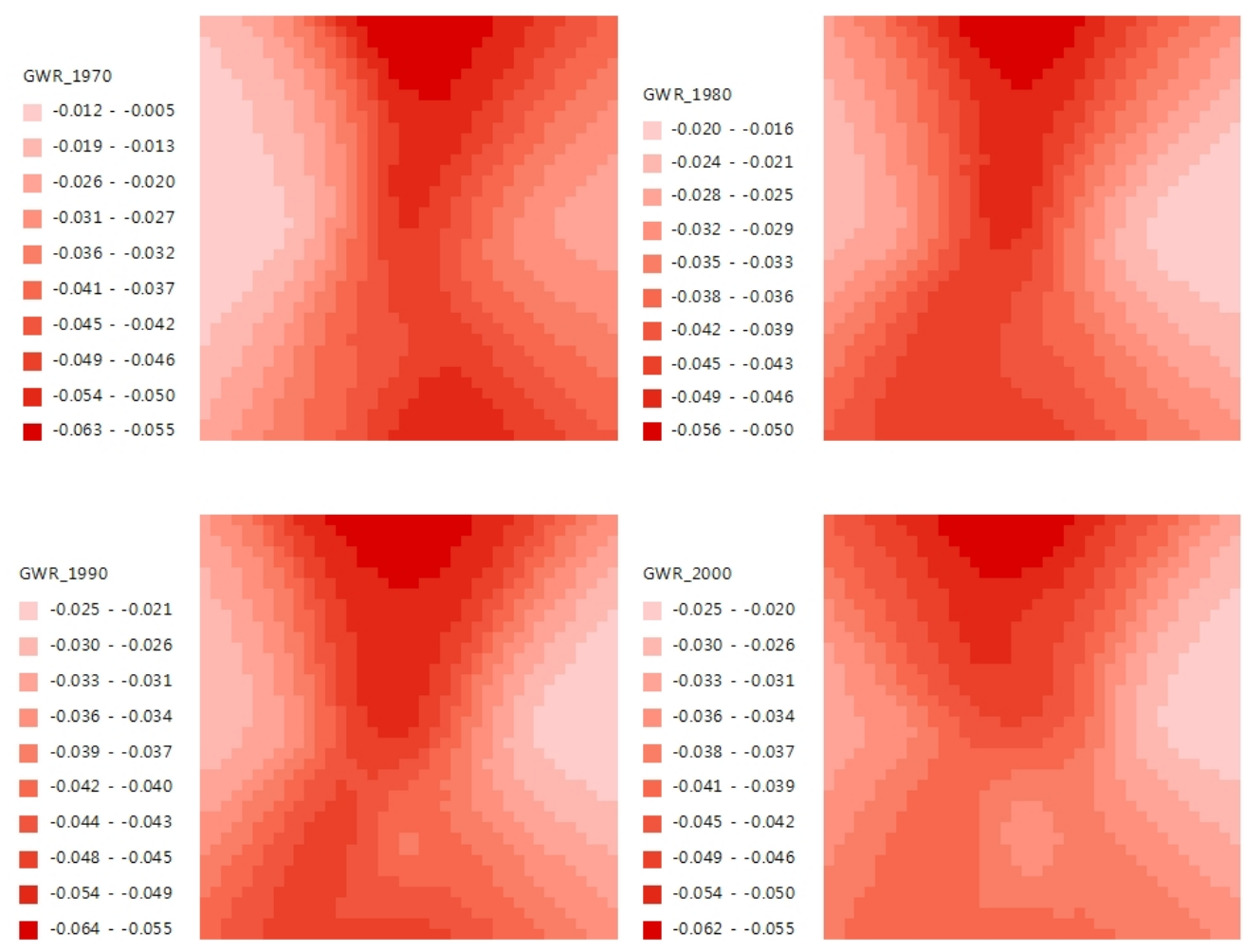

Figure 6. Urbanization coefficients from the Geographically Weighted Regression model with 1600 grid cells for $1970-2000$

Table 2 shows that the explanatory power of the GWR model decreased as time progressed. Increased urbanization made the geographical structure of the study region more complex. The table also shows that the model's explanatory power improved when the cell size decreased, because smaller cells better represent the spatial variations. The AICc values increased with large magnitudes when the cell size decreased, indicating meaningful improvements of the model's explanatory power.

Table 2. Decreasing $R^{2}$ in the GWR models with increasing cell sizes from 1970 to 2000

\begin{tabular}{c|c|r|r|r|r}
\hline Year & Grid & \multicolumn{1}{c|}{ Residual Squares } & \multicolumn{1}{c|}{ AICc } & \multicolumn{1}{c|}{$\mathbf{R}^{2}$} & \multicolumn{1}{c}{$\mathbf{R}^{2}$ Adjusted } \\
\hline \hline \multirow{3}{*}{1970} & $20 \times 20$ & 1224630.1554 & 4367.9455 & 0.7963 & 0.7903 \\
\cline { 2 - 6 } & $30 \times 30$ & 2158210.1551 & 9585.0157 & 0.8410 & 0.8383 \\
\cline { 2 - 6 } & $40 \times 40$ & 3308092.4483 & 16784.9951 & 0.8630 & 0.8615 \\
\hline \multirow{3}{*}{1980} & $20 \times 20$ & 2586657.6146 & 4660.9399 & 0.6288 & 0.6216 \\
\cline { 2 - 6 } & $30 \times 30$ & 2712383.9096 & 9791.1129 & 0.8274 & 0.8245 \\
\cline { 2 - 6 } & $40 \times 40$ & 4097426.3684 & 17127.8326 & 0.8536 & 0.8520 \\
\hline \multirow{3}{*}{1990} & $20 \times 20$ & 3494293.2470 & 4781.2959 & 0.6442 & 0.6373 \\
\cline { 2 - 6 } & $30 \times 30$ & 3671512.3299 & 10063.7548 & 0.8343 & 0.8314 \\
\cline { 2 - 6 } & $40 \times 40$ & 5525072.0645 & 17606.2667 & 0.8599 & 0.8583 \\
\hline
\end{tabular}




\begin{tabular}{l|l|r|r|r|r}
\multirow{2}{*}{2000} & $20 \times 20$ & 3512936.5794 & 4783.5227 & 0.6467 & 0.6397 \\
\cline { 2 - 7 } & $30 \times 30$ & 3883833.8786 & 10114.6356 & 0.8272 & 0.8241 \\
\cline { 2 - 7 } & $40 \times 40$ & 5952920.2574 & 17725.8685 & 0.8512 & 0.8495 \\
\hline
\end{tabular}

\section{Changes in land use / cover}

Figure 7 compares the areal extent of the three land use classes (transportation, industrial and commercial, and residential) and the sum of their areal extent in square kilometers in 1963 and 2000 in the zones of high, moderate, and low permeability. Overall, the zone of moderate recharge potential has always contained the largest extent of urban areas of the land use classes. This is probably due to the fact that it underlies the largest area of Waukesha County with slightly more square kilometer than the zones of high and low permeability combined. However, the high permeability zone showed the fastest urban growth between 1963 and 2000. The urban areas more than doubled in the high permeability zone, mostly due to the growth of residential areas. The urban areas in the low and moderate permeability zones also increased substantially, by more than $76 \%$. In 1963, urban areas occupied $16 \%$ of the high permeability zone but they occupied $39 \%$ in 2000 . 
Urban Land Use Classes I, II, III

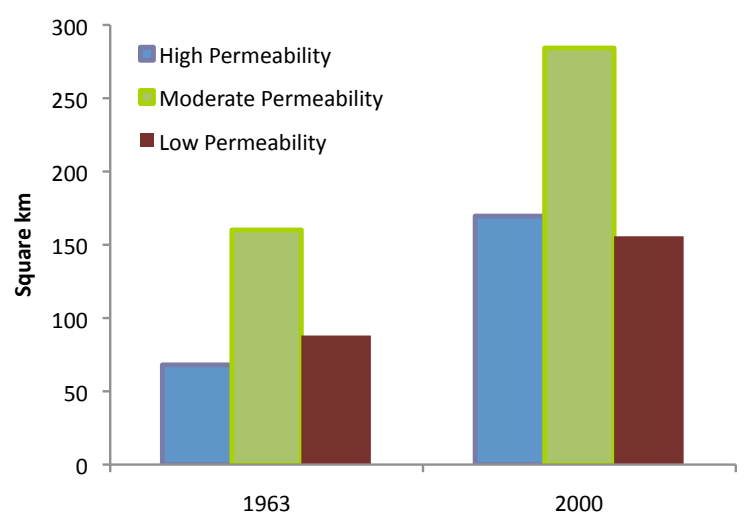

Land Use Class II: Industrial and Commercial

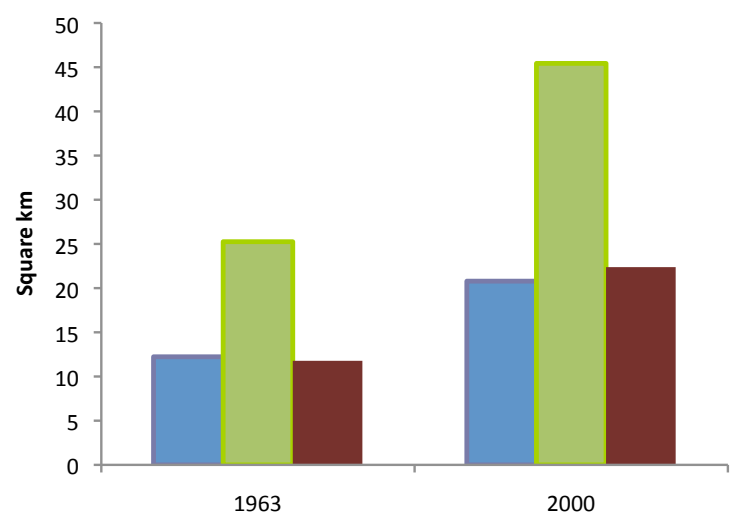

Land Use Class I: Transportation

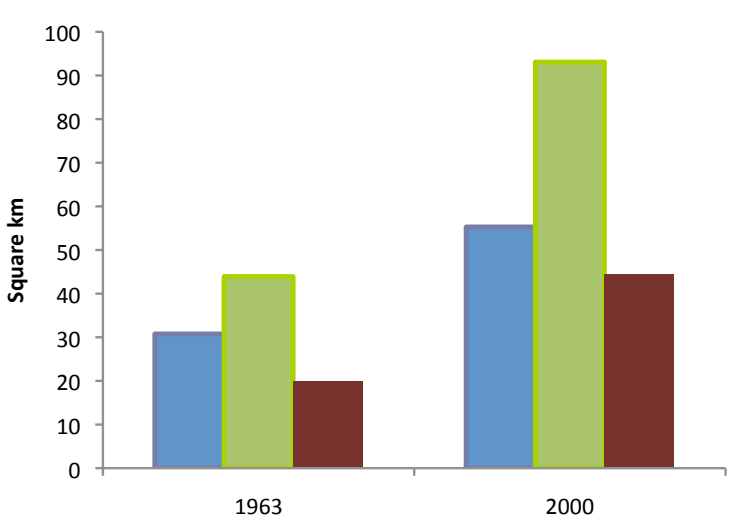

Land Use Class III: Residential

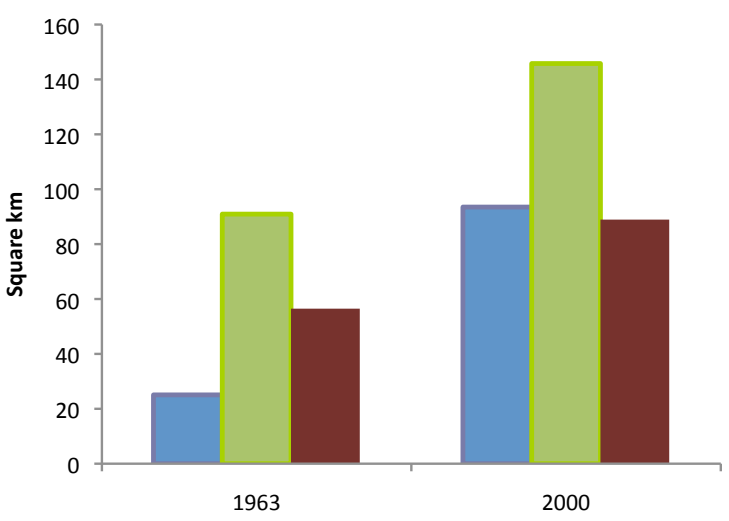

Figure 7. Areal extent of the land use classes residential, industrial and commercial, and transportation in the zones of high, moderate and low permeability in 1963 and 2000

Figure 8 shows the total increase in urban development (land use classes I, II, III, and IV) in Waukesha County between 1963 and 2000 and confirms that new urban development was added extensively in the western part of the county and not only close to previous urban development in the eastern portion of the county where the low permeability zone is situated. The western part of the county had been largely undeveloped until 1963. New residential development has been the most dominant form of urban growth occurring in Waukesha County between 1963 and 2000. The majority of new development since then was located in moderate and high permeability zones which favor natural groundwater recharge through infiltration. 


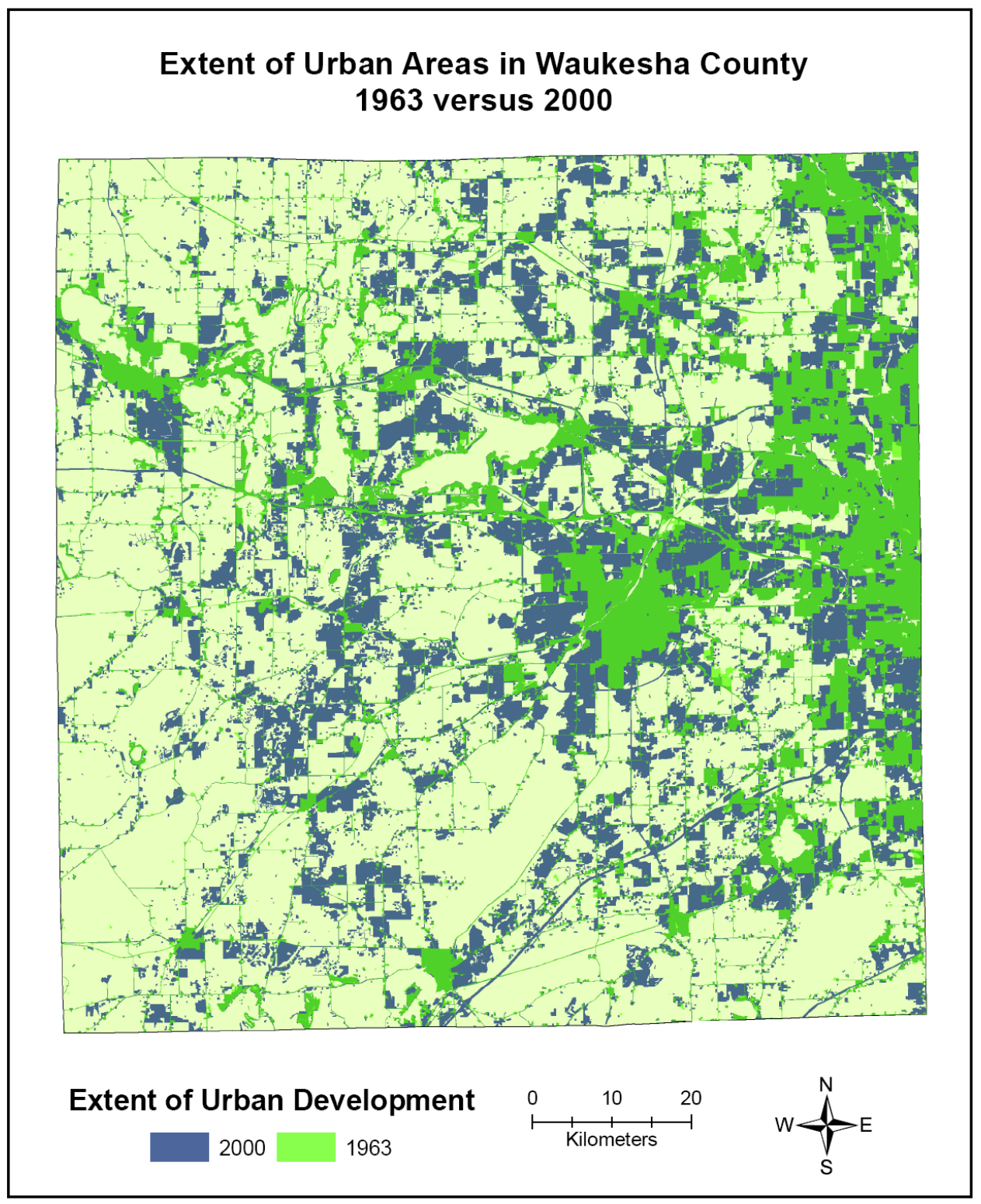

Figure 8. Extent of urban areas in Waukesha County in 1963 and 2000

Figure 9 shows that the overall perimeter-to-area ratio of urban development in Waukesha County has been declining since the 1960s. Generally perimeter-to-area ratios tend to increase with urbanization because developed areas become more complex in shape (Hwang 2010), but this is not the case in Waukesha County. In 2000 the perimeter-to-area ratio was still twice as large in areas of high permeability as compared to the perimeter-to-area ratio of urban areas in areas of low subsurface permeability. This means that the negative impact of urban areas in the areas of high recharge potential in Waukesha County is enhanced by their high perimeter-to-area ratio and is lower in areas of low permeability due to the smaller perimeter-to-area ratio. 


\section{Perimeter to Area Ratio of Urban Areas}

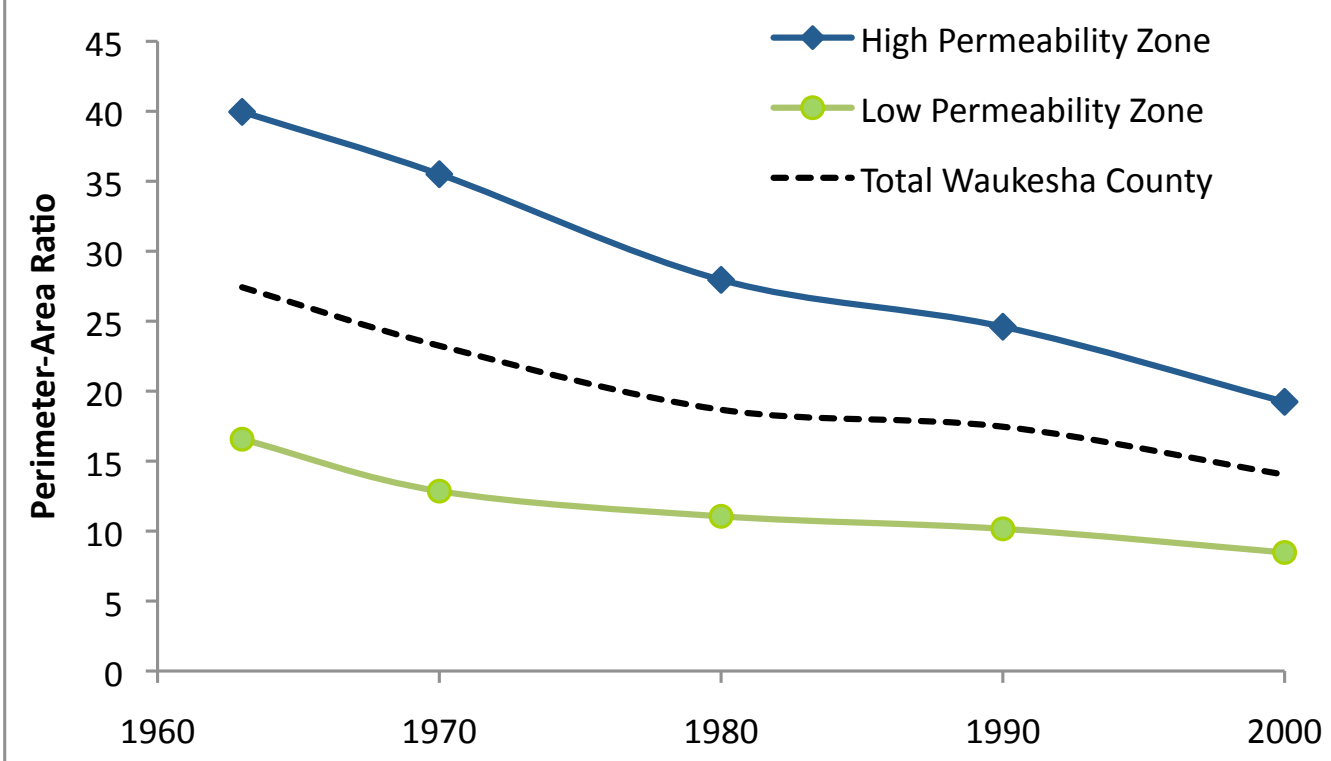

Figure 9. Changes of perimeter-to-area ratio of urban areas (I, II, III) in Waukesha County between 1963 and 2000

\section{Changes in potentiometric surface in space and time}

Figure 10 shows the change in potentiometric surface in meters above mean sea level for high and low permeability zones between 1900 and 2000 along with the groundwater withdrawal in each zone. The potentiometric surface has declined more sharply in the zone of low permeability than in the zone of high permerability, both relatively and absolutely. The changes in the entire county and in the moderate permeability zone are between the high and low permeability zones (not shown). The difference in the decline of the potentiometric surface is in part related to different rates of groundwater withdrawals in the high and low permeability zones. The figure shows that the withdrawal of groundwater increased more shraply in the zone of low permeability than in the zone of high permeability. In fact, the amount of groundwater withdrawal in the high permeability zone has decreased slightly since 1980. Higher levels of groundwater were withdrawn in areas of low recharge potential than in areas with high permeability which allows much higher rates of natural groundwater recharge. Waukesha County did not match groundwater withdrawal rates in some form to the groundwater recharge rates of the area, where the groundwater was withdrawn. Therefore, due to higher recharge, the negative impact of withdrawal is not as negative in areas of high permeability as it is in areas of low permeability. 


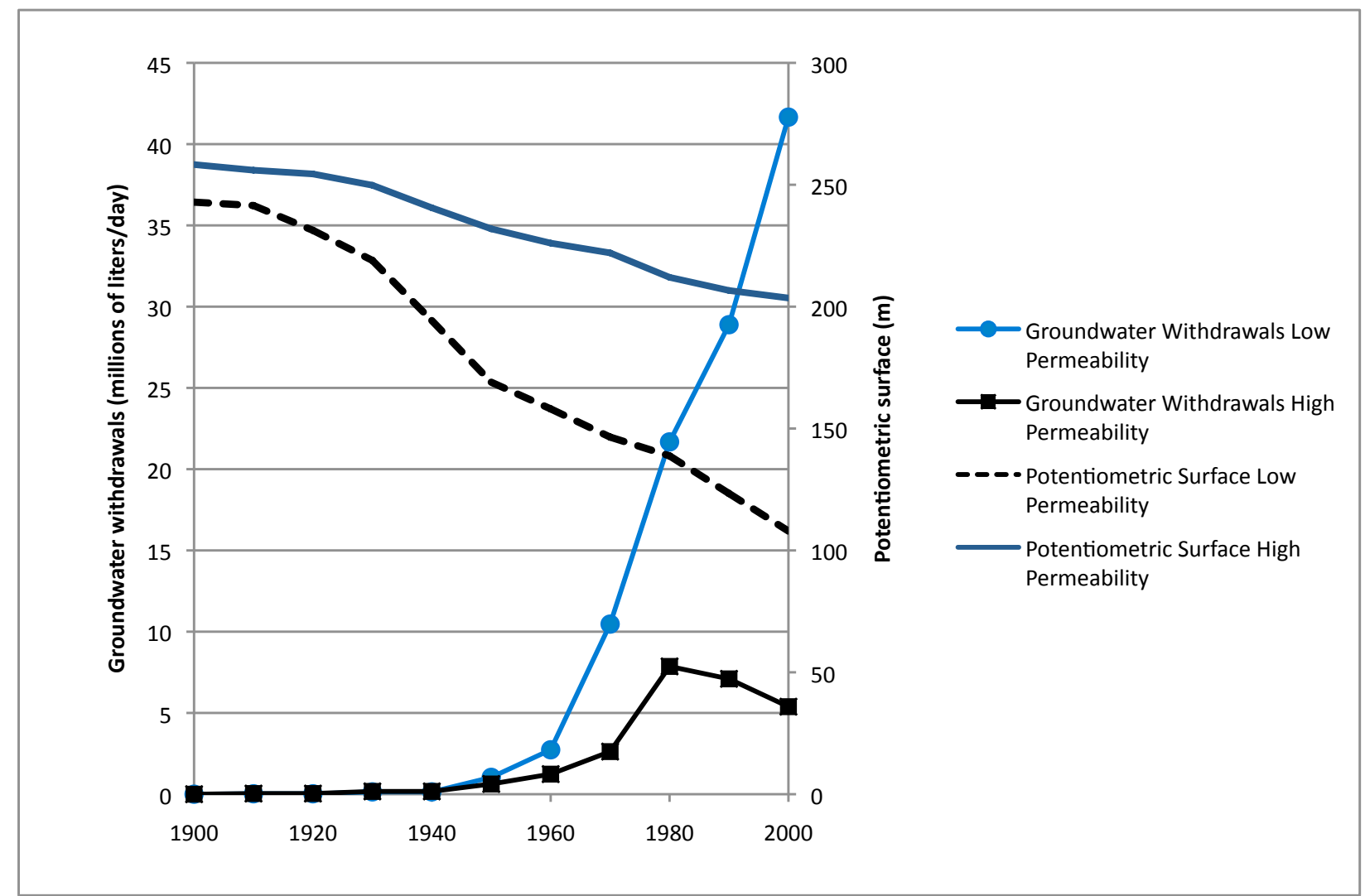

Figure 10. Trends of potentiometric surface level and groundwater withdrawals for the high and low permeability zones in Waukesha County

Figure 11A shows that the change in potentiometric surface has been more drastic in the east of the county with a drop of more than 129 meters while in the west there is still a small area the potnetiometric surface has not changed since 1900 . The low permeability zone in the east side of the county clearly coincides with dramatic decreases in the potentiometric surface as shown in Figure 10. 


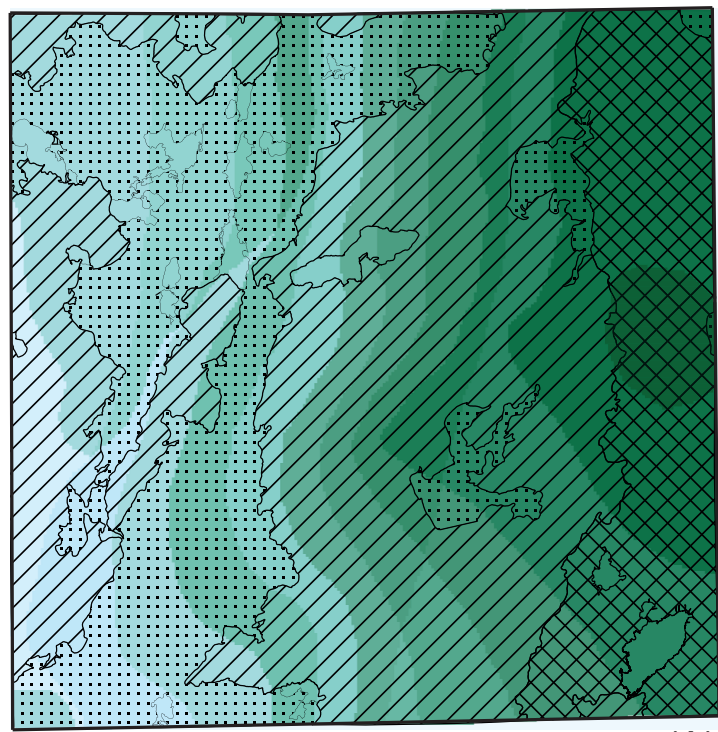

(A)

Decrease in Potentiometric Surface

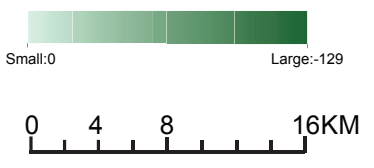

Subsurface Permeability

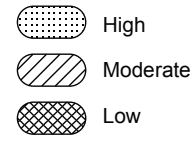

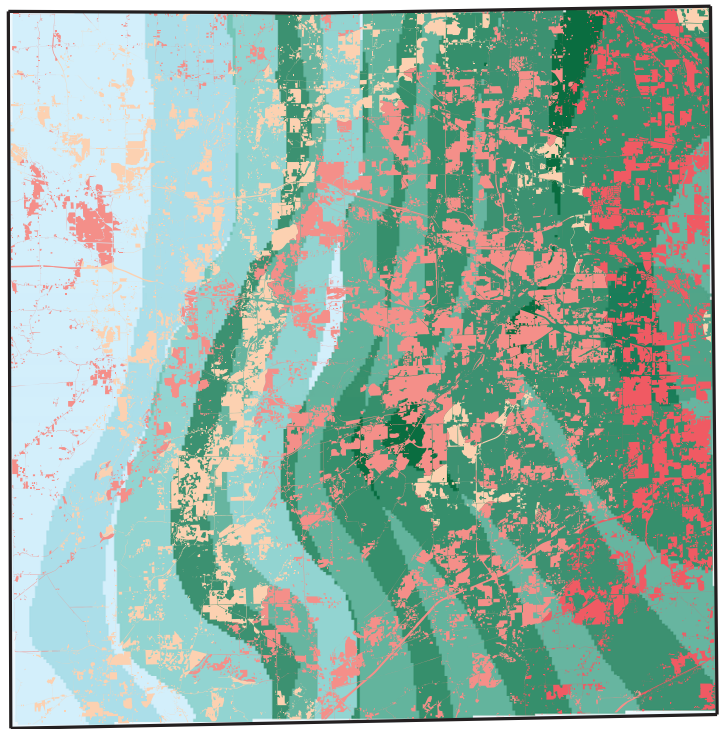

(B)

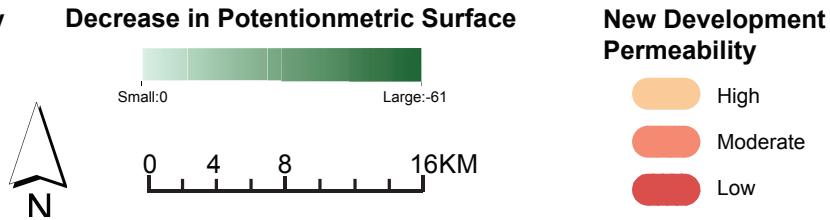

Figure 11. Decrease in potentiometric surface in meters above mean sea level between 1900 and 2000 (panel A) and between 1963 and 2000 (panel B)

Figure 11B shows the change in potentiometric surface between 1963 and 2000. The map is overlaid by the location of new urban development during the period stratified by the permeability zone. The figure shows that the potentiometric surface declined more rapidly in the eastern part of the county than in the western part. Urban areas increased substantially in the central and eastern part of the county during the period, where recharge potential is moderate or low, and thus groundwater withdrawal. One can see a distinct band of large potentiometric decreases stretching from north to south in the west-central corridor of the county. The band approximately coincides with new urban development in the high permeability zone. There are also a few wells along the band where groundwater withdrawal increased significantly. Therefore, in the area where groundwater recharge potential is high, two activities that generally negatively affect groundwater level, urban development and groundwater withdrawal, occurred at the same time. A gradual decline can be seen towards the western boarder of the county which might be related to urban development spreading westwards, since the flow of groundwater from western parts of the county to groundwater depleted areas in the east is very slow and could not account for the increased depletion (GLWI 2007). 


\section{Discussion}

We found that the groundwater level, represented by the potentiometric surface, continuously declined in Waukesha County, and the decline was strongly correlated with the degree of urbanization and groundwater withdrawal. Across the county, the potentiometric surface had logarithmic relations with the degree of urbanization and groundwater withdrawal, indicating that the marginal effect on potentiometric surface will be smaller and smaller with increasing urbanization and groundwater withdrawal. The logarithmic relationship between groundwater levels and the degree of urbanization found in this study is quite unique. An apparently linear relationship between annual recharge rate (percent of precipitation) and imperviousness was reported by Erickson and Stefan (2009), but many other relevant studies did not explicitly reveal the relationship between groundwater level and the degree or urbanization or water withdrawal.

The Geographically Weighted Regression (GWR) models in our study showed spatial variations of the effect of urbanization on the groundwater level at different times. The GWR models found that the effect of urbanization on the groundwater level is stronger in the central part of the county while weaker in eastern and western parts. As urbanization continued with time, the effect tended to weaken throughout the county. Even though GWR has been extensively used in various applications (Wentz and Gober 2007), just a few water studies (Tu and Xia 2008; Wentz and Gober 2007; Wooldridge et al. 2006) adopted it and it has never been used for explicit groundwater research. Wentz and Gober (2007), for example, built GWR models for each census tract of a metropolitan area for water use, and others did for water quality sampling sites. These aforementioned studies and the present study pinpoint the importance of spatial data in surface and groundwater research. We were able to apply GWR largely thanks to the existence of the potentiometric surface data and land use data that could be easily converted to a grid mesh. Since the data were available for different times as well, we could examine the effect of urban growth on groundwater level both spatially and temporally. The regression models by Lorenz and Delin (2007) showed the spatial variation of groundwater recharge across Minnesota, but could not explain which explanatory variables are more important and where. A limitation of this study is that in-depth analyses of the GWR results were not conducted, and we defer them to the next step.

The study found that the decline of potentiometric surface is spatially inhomogeneous, and urban development expanded where groundwater recharge potential is high. Between 1900 and 2000 urban development in Waukesha County spread westwards and consequently contour lines of low potentiometric surface kept moving westward as well. In areas of high subsurface permeability, impervious urban surfaces intercepting the recharge were highly correlated with the potentiometric surface level. On the other hand, in areas of low subsurface permeability, total groundwater withdrawals were most highly correlated with potentiometric surface levels. Impermeable surfaces in areas of highest recharge potential will have the largest negative impact on groundwater recharge. An increase in impermeable 
surfaces can be expected to be least negative in areas of low or no recharge potential. The results indicate that invisible geological characteristics of the subsurface, as in this case the level of permeability, and their relationship to urban areas cannot be ignored when discussing the sustainable management of groundwater resources.

We note that an increase in precipitation during the last several decades did not outweigh the groundwater decline due to human activity in the high permeability zone. The increasing precipitation and the decreasing potentiometric surafce in Waukesha County indicate the greater role of human actitivies that negatively affect groundwater recharge. It tells that climate change can be another stress factor for groundwater resources in Waukesha County. Fortunately annual precipitation is projected to moderately increase between 1980-1999 and 2080-2099 according to many climate models (Christensen et al. 2007), but in the event that precipitation decreases in the future, it will exacerbate the groundwater stress.

\section{Conclusions}

The objective of the study was to spatially and temporally analyze the groundwater level change in relation to urban development and groundwater recharge potential. We analyzed land use/cover, precipitation, potentiometric surface as groundwater level, and groundwater withdrawal data for Waukesha County, Wisconsin to accomplish this objective. We found that (1) Urban areas increased faster in areas with high recharge potential than in areas with low or moderate recharge potential in the county, (2) The effect of urban growth on groundwater level is highly variable by time and space, and (3) The changes in groundwater level are strongly related to the spatial distribution of groundwater withdrawal. Our research also reveals that both groundwater withdrawal and urban development increased in a large amount in the area where recharge potential is high. The study indicates that it is vital to consider groundwater recharge potential that varies spatially for better understanding the change in groundwater level.

\section{Acknowledgement}

Some of the maps were produced with help from the Cartography and Geographic Information Systems Center at the University of Wisconsin-Milwaukee. Anne Bonds provided helpful comments on the manuscript.

\section{References}


Buchwald, C. A., C. L. Luukkonen, and C. M. Rachol. 2010. Estimation of Groundwater Use for a Groundwater-flow Model of the Lake Michigan Basin and Adjacent Areas, 1864-2005. U.S. Geological Survey, Report Number, U.S. Geological Survey Scientific Investigations Report 2010-5068.

Cho J, Barone VA, Mostaghimi S (2009) Simulation of land use impacts on groundwater levels and streamflow in a Virginia watershed. Agric.Water Manage. 96:1-11

Christensen, J. H., B. Hewitson, A. Busuioc, A. Chen, X. Gao, I. Held, R. Jones, R. K. Kolli, W. -. Kwon, R. Laprise, V. Magana Rueda, L. Means, C. G. Menendez, J. Raisanen, A. Rinke, A. Sarr, and P. Whetton. 2007. Regional Climate Projections. In Climate Change 2007: The Physical Science Basis. Contribution of Working Group I to the Fourth Assessment Reprot of the Intergovernmental Panel on Climate Change, ed. S. Solomon, D. Qin, M. Manning, Z. Chen, M. Marquis, K. B. Averyt, M. Tignor and H. L. Miller, 847-940. Cambridge, UK and New York, USA: Cambridge University Press

Dripps WR, Bradbury KR (2007) A simple daily soil-water balance model for estimating the spatial and temporal distribution of groundwater recharge in temperate humid areas. Hydrogeol.J. 15:433-444

Erickson TO, Stefan HG (2009) Natural Groundwater Recharge Response to Urbanization: Vermillion River Watershed, Minnesota. Journal of Water Resources Planning and Management-Asce 135:512-520

Fotheringham AS, Brunsdon C, Charlton ME (2002) Geographically Weighted Regression: The Analysis of Spatially Varying Relationships. Wiley, Chichester

GLWI. Q \& A: Water Issues in Waukesha. In Great Lakes Water Institute [database online]. Milwaukee, Wisconsin, 2007 Available from http://www.glwi.uwm.edu/ourwaters/documents/WaukeshaHandoutBWeb.pdf (last accessed 01/19 2011).

He B, Wang Y, Takase K, Mouri G, Razafindrabe BHN (2009) Estimating Land Use Impacts on Regional Scale Urban Water Balance and Groundwater Recharge. Water Resour.Manage. 23:1863-1873

Hwang C (2010) Exploring land-use and land-cover change based on the small cadastral units. The Geographical Journal of Korea 44:229-241

Jaiswal RK, Mukherjee S, Krishnamurthy J, Saxena R (2003) Role of remote sensing and GIS techniques for generation of groundwater prospect zones towards rural development - an approach. Int.J.Remote Sens. 24:993-1008

Jasrotia AS, Kumar R, Saraf AK (2007) Delineation of groundwater recharge sites using integrated remote sensing and GIS in Jammu district, India. Int.J.Remote Sens. 28:5019-5036

Jat MK, Khare D, Garg PK (2009) Urbanization and its impact on groundwater: a remote sensing and GIS-based assessment approach. Environmentalist 29:17-32

Lorenz DL, Delin GN (2007) A regression model to estimate regional ground water recharge. Ground Water 45:196-208

Rose S, Peters NE (2001) Effects of urbanization on streamflow in the Atlanta area (Georgia, USA): a comparative hydrological approach. Hydrol.Process. 15:14411457 
SEWRPC. 2004. The Population of Southeastern Wisconsin. Waukesha, Wisconsin: Southeastern Wisconsin Regional Planning Commission, Report Number, Technical Report No. 11(4).

2002. Groundwater Resources of Southeastern Wisconsin. Waukesha, Wisconsin: Southeastern Wisconsin Regional Planning Commission, Report Number, Technical Report No. 37.

Shaban A, Khawlie M, Abdallah C (2006) Use of remote sensing and GIS to determine recharge potential zones: the case of Occidental Lebanon. Hydrogeol.J. 14:433-443

Tu J, Xia Z (2008) Examining spatially varying relationships between land use and water quality using geographically weighted regression I: Model design and evaluation. Sci.Total Environ. 407:358-378

Vazquez-Sune E, Sanchez-Vila X, Carrera J (2005) Introductory review of specific factors influencing urban groundwater, an emerging branch of hydrogeology, with reference to Barcelona, Spain. Hydrogeol.J. 13:522-533

Wentz EA, Gober P (2007) Determinants of small-area water consumption for the city of Phoenix, Arizona. Water Resour.Manage. 21:1849-1863

Wooldridge S, Brodie J, Furnas M (2006) Exposure of inner-shelf reefs to nutrient enriched runoff entering the Great Barrier Reef Lagoon: Post-European changes and the design of water quality targets. Mar.Pollut.Bull. 52:1467-1479

Yeh HF, Lee CH, Hsu KC, Chang PH (2009) GIS for the assessment of the groundwater recharge potential zone. Environ.Geol. 58:185-195

Zellner ML (2007) Generating policies for sustainable water use in complex scenarios: an integrated land-use and water-use model of Monroe County, Michigan. Environment and Planning B-Planning \& Design 34:664-686 